\title{
Periodization of the development of local fashion brand in Bandung in 1994-2018
}

\author{
W.N.U. Bastaman, A.S. Hardy Shafii \\ Universiti Sains Malaysia, Penang, Malaysia \\ R. Febriani \\ Telkom University, Bandung, Indonesia
}

\begin{abstract}
Bandung, known as the city of education, has attracted many people from various regions, helping to build an open and diverse atmosphere. Its proximity to Jakarta (Place), the capital of Indonesia and the largest business center in the country, allowed Bandung to receive information on the latest trends and business. These two aspects were then able to give birth to many new ideas, one of which was the phenomenon of the emergence of local fashion brands in Bandung in the late 1990s which continue to grow today. This research maps out Bandung's local fashion brand from 1994-2018, based on their periodization and genre. This mapping is expected to be a reference for designers, crafters, entrepreneurs, and industry stakeholders to develop Bandung's local fashion brand in the future. This research uses qualitative methods through literature study and secondary data, further reinforced by interviewing influential designers and people in the industry. As a result, it can be concluded that Bandung has experienced three periodizations of development of local fashion brands.
\end{abstract}

Keywords: local brand, Bandung, creative industry

\section{INTRODUCTION}

Bandung is the capital of the West Java Province and the 5th largest city in Indonesia. It has long been known for its beautiful, natural potential. Because of its good air quality, the city of Bandung was also planned as the Dutch East Indies' capital replacing Batavia (Kunto 2014). Its geographical location (Place) naturally attracts many people to stay in Bandung. Besides that, the location, with its proximity to Jakarta, makes Bandung able to easily receive information on the latest trends. Bandung is also known as a city of education, another important aspect as it attracts many young people to live there. The number of young people in Bandung has reached $60 \%$ of the total population (People) (Resmadi 2017). The existence of young people with various backgrounds creates an atmosphere of openness in Bandung, and this conversation then produced ideas for their environment thereby increasingly making the city of Bandung a more livable place (Bandung Dossier Team 2013).

Places, people, and ideas are three strengths of Bandung (Ekomadyo et al. 2016). These three strengths had a significant impact on the city of Bandung in the 1990s. The phenomenon resulted in the birth of a fashion brand in Bandung, which was then widely adopted in various other cities in Indonesia. This phenomenon was also reinforced by the emergence of Western popular culture in Bandung in the 1970s through music (Yujin 2017). According to data from the Ministry of Cooperatives and Small and Medium Enterprises and the Office of Trade and Industry, the number of local fashion brands in Bandung in 2012 reached 551. However, in fact, the number may be more than that because there are still many local fashion brands that only operate online and do not have a brick and mortar store. Therefore, they are not considered official business entities and 
so not listed (Soei et al. 2015). The KICKFEST event was the first clothing festival in Indonesia originating from the city of Bandung. It took place in September 2019 in Malang, with the number of local brands participating reaching 100. In addition, the Brightspot Market event was held in October 2019 in Jakarta, where 150 local brands participated. Because of this potential, Bandung was initiated as a creative city in 2015 (Aritenang 2012; Irawati \& Nasional 2011; Unesco 2015). Through this research, researchers will map the development of a local fashion brand based on each period's periodization and distinct features. This mapping is expected to be a reference for designers, crafters, entrepreneurs, and stakeholders to develop Bandung's local fashion brand in the future.

\section{METHODOLOGY AND DISCUSSION}

The research was conducted using qualitative methods through document studies and in-depth interviews from 2018-2019. Researchers interviewed the owner and Creative Director of some of the leading fashion brands in Bandung who had been in business 5-10 years. Interviews were conducted in semi-structured interviews and direct observation. Researchers visited the actual store and observed the social media of local brands. The data obtained through these documents, such as data from journals, books, and popular articles, were compared with interviews. Based on these data, the mapping of periodization, actors, local brands that developed at that time is known, and other important events impact further developments.

\subsection{Pioneer Era (1994-1996)}

Table 1. The Pioneer Era (1994-1996)

\begin{tabular}{|c|c|c|c|c|c|c|}
\hline 1906-1983 & 1970 & 1983 & 1990 & 1993 & 1994 & 1996 \\
\hline $\begin{array}{l}\text { Bandung } \\
\text { History } \\
\text { Dutch } \\
\text { Colonial } \\
\text { (1906-1945) } \\
\text { until New } \\
\text { Order Era } \\
\text { (1983): } \\
\text { Westernized }\end{array}$ & $\begin{array}{l}\text { Birth of } \\
\text { Aktuil music } \\
\text { magazine } \\
(1970) \text {, rock } \\
\text { and British } \\
\text { music } \\
\text { invasion }\end{array}$ & $\begin{array}{l}\text { - Press } \\
\text { restriction } \\
\text { - Foreign } \\
\text { media enter } \\
\text { Indonesia } \\
\text { - Mainstream } \\
\text { music start } \\
\text { to raise }\end{array}$ & $\begin{array}{l}\text { - MTV } \\
\text { - ESPN: } \\
\text { skateboard- } \\
\text { ing } \\
\text { - Punk, } \\
\text { hardcore, } \\
\text { metal music } \\
\text { communi- } \\
\text { ties thrived } \\
\text { underground }\end{array}$ & $\begin{array}{l}\text { Pas Band } \\
\text { (under- } \\
\text { ground } \\
\text { band) } \\
\text { recording } \\
1^{\text {st }} \text { album }\end{array}$ & $\begin{array}{l}\text { - DIY spirit } \\
\text { - Reverse Studio } \\
\text { Music established } \\
\text { (Dxxxt, Helvi, } \\
\text { Richard Mutter) and } \\
\text { develop become to } \\
\text { Reverse Clothing } \\
\text { Company } \\
\text { - The rise of punk, } \\
\text { metal, hardcore local } \\
\text { band } \\
\text { - The first } \\
\text { skateboarding shop } \\
\text { established }\end{array}$ & $\begin{array}{l}347 \text { established. } \\
\text { This becomes } \\
\text { the pioneer of } \\
\text { Bandung's local } \\
\text { brands. Its } \\
\text { design and } \\
\text { inspired by the } \\
\text { style of } \\
\text { skateboarding } \\
\text { style, music, and } \\
\text { design. }\end{array}$ \\
\hline
\end{tabular}

The first period was The Pioneer Era, which became an important point early at the start of the local fashion brand born in Bandung. Since Bandung was established until the New Order government beginning in 1983, Western lifestyles strongly influence Bandung. In the 1970s, an up-to-date and critical music magazine Aktuil was established which focused on rock music news. During the New Order government, the media were finally restricted. Then the presence of foreign press makes the news circulating tend to be neutral. The era of mainstream music eventually flourished. But punk, hardcore, and metal music continued to grow underground (Resmadi 2018). The presence of TV also brought on a new wave of MTV and ESPN. A new wave of loud music and extreme sports such as skateboarding and BMX further developed into one solid community. In 1993, Pas Band, one of Bandung's underground bands, managed to record an album and distributed it independently. This spirit finally gave birth to the Reverse Music Studio. Here, all underground music, skateboarding, and BMX Bandung communities gather (Resmadi 2017). Reverse Music Studio is also slowly turning into a Reverse Clothing Company. We can find various kinds of band 
merchandise, tapes, artwork, and fashion items related to music, recording, and BMX. In 1996, Bandung's pioneer local fashion brand, 347, was born, which offered fashion items inspired by skateboarding and surfing.

\subsection{Distro and clothing company Era (1997-now)}

Table 2. The Distro and Clothing Company Era (1997-now).

\begin{tabular}{|c|c|c|c|c|c|c|c|}
\hline 1996 & 1997 & 1998 & 2002 & 2006 & 2007 & 2008 & 2012 \\
\hline $\begin{array}{l}\text { The rise of } \\
\text { various } \\
\text { music scene } \\
\& \text { created a } \\
\text { new fashion } \\
\text { trend then } \\
\text { became a } \\
\text { local fashion } \\
\text { brand, Distro } \\
\text { (distribution } \\
\text { store) \& } \\
\text { Clothing } \\
\text { Company }\end{array}$ & $\begin{array}{l}\text { - Asian } \\
\text { Financial } \\
\text { Crisis } \\
\text { - Rupiah } \\
\text { collapsed } \\
\text { - Reverse } \\
\text { Clothing } \\
\text { company } \\
\text { closed } \\
\text { - No more } \\
\text { imported } \\
\text { music } \\
\text { merchandise }\end{array}$ & $\begin{array}{l}\text { - Distro and } \\
\text { clothing } \\
\text { company } \\
\text { began to } \\
\text { design and } \\
\text { produce their } \\
\text { own product } \\
\text { - Also, their } \\
\text { collaboration } \\
\text { with a local } \\
\text { band to } \\
\text { produce their } \\
\text { merchandise } \\
\text { such as } \\
\text { t-shirt. }\end{array}$ & $\begin{array}{l}\text { Many Indonesian } \\
\text { youngsters } \\
\text { imitated the style } \\
\text { of the pioneer } \\
\text { distros and } \\
\text { clothing company } \\
\text { in Bandung itself } \\
\text { and other cities } \\
\text { until now } \\
\text { Besides music, } \\
\text { art, and design, } \\
\text { street style trends } \\
\text { greatly influence } \\
\text { their product } \\
\text { designs }\end{array}$ & $\begin{array}{l}\text { - Kreative } \\
\text { Independent } \\
\text { Creative } \\
\text { Kommunity } \\
\text { (KICK) } \\
\text { established } \\
\text { - In collaboration } \\
\text { with the } \\
\text { Indonesian } \\
\text { Ministry of } \\
\text { Industry, KICK } \\
\text { held Bandung } \\
\text { Indie Clothing } \\
\text { Expo } \\
\text { - Internet is easier } \\
\text { to access. Social } \\
\text { media such as } \\
\text { Friendster is used } \\
\text { widely. }\end{array}$ & $\begin{array}{l}\text { First } \\
\text { KICKFEST } \\
\text { held in } \\
\text { Bandung and } \\
\text { still held } \\
\text { annually until } \\
\text { now in } \\
\text { various cities } \\
\text { in Indonesia }\end{array}$ & $\begin{array}{l}\text { Facebook } \\
\text { is widely } \\
\text { used. }\end{array}$ & $\begin{array}{l}\text { - The offline } \\
\text { store starting } \\
\text { to shift to an } \\
\text { online store } \\
\text { - Several distros } \\
\text { and clothing } \\
\text { companies } \\
\text { began to } \\
\text { collapse }\end{array}$ \\
\hline
\end{tabular}

After the Reverse Clothing Company and 347 were established, many of the local fashion brands were developed. Some local fashion brands will eventually be able to have independent distribution or offline stores. Otherwise, it will usually join a particular Distro (distribution store) and use the sales consignment system. The term "Distro" has come to represent a local brand that stands for this era, whether it has independent offline stores or not (Kim 2017). Unfortunately, in 1997, the Asian financial crisis occurred, and the Rupiah collapsed. Reverse Clothing Company that were focusing on the sale of imported merchandise products collapsed. In 1998, to overcome difficulties after the economic crisis, the system focused on designing and locally producing its products (Irawati \& Nasional 2012), and began actively collaborating with a variety of local musicians at the time and bringing the community to become the main consumer. In 2006, a community was finally created to accommodate a local fashion brand called the Kreative Independent Creative Community (KICK). It began with a showcase and bazaar and performances from local musicians. The event continues to be held every year since, not only in Bandung but in other major Indonesian cities as well. In 2008, when Facebook began to be widely used, the product sales process began to change becoming online. At its peak in 2012, the distro slowly began to collapse. Local fashion brands that have survived until now can adapt to challenge and have a strong community behind them.

\subsection{Local brand Era (2008-now)}

The last period is the local brand era. After the Distro and Clothing Company era, local fashion brands are varied and known by the term "Local Brand". In 2008, Happy Go Lucky was born, the first curated store in Bandung. Saadiah Adzani (2019), former Creative Director of Happy Go Lucky, said the concept is similar to Distro, which collects several local fashion brand products in one place but with the thematic theme. If Distros are very thick about local musicians, a curated store comes with current fashion trends. This was followed by the first curated local fashion brand event in Jakarta, Brightspot Market. Similar to Brightspot Market, Bandung also held the Trademark Market and the Lookats Market. The online shopping phenomenon started spreading in 2010. Iqra Tanzil (2018), Creative Director from Imagery Bags, said besides Facebook, there are also new 
Table 3. The Local Brand Era (2008-now)

\begin{tabular}{|c|c|c|c|c|c|c|}
\hline 2008 & 2009 & 2010 & 2011 & 2013 & 2014 & 2017 \\
\hline $\begin{array}{l}\text { Happy Go } \\
\text { Lucky or } \\
\text { well known } \\
\text { as HGL, the } \\
\text { first curated } \\
\text { local brand } \\
\text { store, } \\
\text { established } \\
\text { in Bandung }\end{array}$ & $\begin{array}{l}\text { - First } \\
\text { Brightspot } \\
\text { Market held } \\
\text { in Jakarta. } \\
\text { - Brightspot } \\
\text { Market } \\
\text { become a } \\
\text { barometer } \\
\text { for similar } \\
\text { events in } \\
\text { other cities, } \\
\text { especially in } \\
\text { Bandung. }\end{array}$ & $\begin{array}{l}\text { - Facebook, } \\
\text { Kaskus, and } \\
\text { Blackberry are } \\
\text { widely used as a } \\
\text { marketing } \\
\text { channel and the } \\
\text { "online } \\
\text { shopping" } \\
\text { phenomenon } \\
\text { began to spread } \\
\text { - Brodo, a } \\
\text { footwear brand, } \\
\text { established } \\
\text { Trademark } \\
\text { Market held in } \\
\text { Bandung }\end{array}$ & $\begin{array}{l}\text { Kaskus thread: } \\
\text { Indonesian } \\
\text { Brands } \\
\text {-One Stop } \\
\text { Fashion News- } \\
\text { established }\end{array}$ & $\begin{array}{l}\text { Instagram began } \\
\text { to be widely } \\
\text { used as a } \\
\text { marketing } \\
\text { channel and } \\
\text { made people } \\
\text { easier to online } \\
\text { shopping }\end{array}$ & $\begin{array}{l}\text { Local brand } \\
\text { starting with } \\
\text { social media and } \\
\text { building web } \\
\text { stores }\end{array}$ & $\begin{array}{l}\text { - People familiar } \\
\text { with the } \\
\text { marketplace } \\
\text { (Tokopedia, } \\
\text { Shopee, Zalora, } \\
\text { etc.) } \\
\text { - Some local } \\
\text { brands also } \\
\text { launched } \\
\text { physical stores }\end{array}$ \\
\hline
\end{tabular}

information platforms, such as Kaskus and BlackBerry Message Group. With more open access to information from the Internet, a new concept of local fashion brands emerged. Agit Bambang from Amble Footwear and Fahmi from Hijack Sandals (2019) said that the Local Brand has its specialty, such as footwear, bags, or jewelry. This is different from the Distro that provides the entire product from head to toe. Anya Kardin from Kar Jewelry (2019) said that Instagram's birth opened up online shopping opportunities. Although the Local Brand already has a website, major sales channels are still through WhatsApp, Line, email, or marketplace. However, in the last three years, people are more familiar with using the site and the advent of markets that generally use the website base.

\section{CONCLUSION}

The local fashion brand in Bandung experienced three periods of development. Distro, Clothing Company, or Local Brand are local fashion brands. The name Distros is already attached to several local fashion brands born in the late 1990s or 2000s. In the era of Distro and Clothing Company, more focus is on developing apparel products that complement one another from head to toe, making the products offered more specialized in the period of Local Brands. Distro or Clothing Company, generally very attached to a particular music genre or music community. But in Local Brands usually, they complement each other to define specific communities. This research is expected to provide a map of local brand development periodization in Bandung's city. It could guide young entrepreneurs to understand business development in Bandung and allow them to make business forecasts.

\section{REFERENCES}

Aritenang, Adiwan. 2012. The City of Bandung: Unfolding the Process of a Creative City. SSRN Electronic Journal. 10.2139/ssrn.2295227.

Ekomadyo, Agus Suharjono \& Pradita Candrawati. 2016. Kriteria Placemaking untuk Fashion Hub. Prosiding Temu Ilmiah IPLBI 2016.

Bandung Dossier Team. 2013. UNESCO City of Design Bandung. Application.Bdg.

Data Statistik dan Hasil Survei EKONOMI KREATIF Kerjasama Badan Ekonomi Kreatif dan Badan Pusat Statistik. 2016.

Ekonomi Kreatif Bandung. 2018. http://creativeconomy.bandung.go.id/. Https://en.unesco.org/creativecities/bandung (2015) 
Irawati, I. and Nasional, I. T. 2011. City as Idea Generator for Creative Industries: Case Study: Bandung's Creative Industry (Clothing and Indie Music Industries). In 3rd World Planning Schools Congress, Perth.

Kim, Y. 2017. Making "Creative" Movement: Transformation of Urban Culture and Politics in Bandung, Indonesia. Geographical Review of Japan Series B, 90(1):17-25.

Kunto, H. 2014. Wajah Bandoeng tempo doeloe. Granesia, Bandung.

Resmadi, I. 2018. Jurnalisme musik dan selingkar wilayahnya. Kepustakaan Populer Grame dia.

Resmadi, Idhar. 2017. Pentingnya Pemikir Desain di Kota Desain. https://idhar- resmadi.net/2017/12/14/ pentingnya-pemikir-desain-di-kota-desain/

Resmadi, Idhar. 2017. Tongkrongan Penting Anak Musik di Bandung Pada 1990-an. https://www. djarumcoklat.com/article/tongkrongan-penting-anak-musik-di-bandung-pada- 1990an

Soei, C. T. L., Satyarini, R., and Prasetya, I. 2015. Identifikasi Key Success Factor pada Indus tri Clothing di Kota Bandung. Research Report-Humanities and Social Science, 2. 


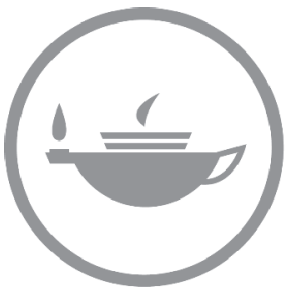

Taylor \& Francis Taylor \& Francis Group

http://taylorandfrancis.com 